\title{
An Examination of the teachings of Ephraim the Syrian and Aphrahat the Persian Sage and their implications for Christian Discipleship in Africa
}

Joshua D. Settles ${ }^{1}$ (D)

${ }^{1}$ Centre for Primal \& Christian Spirituality - Akrofi-Christaller Institute of Theology, Mission and Culture, Akropong - Akuapem, Ghana.

\begin{abstract}
This study is an examination of the teachings of two prominent Christian writers of Syrian Christianity: Ephraim the Syrian, and Aphrahat the Persian. It examines the cultural and religious background that informs their thought. It is a literary study that draws on extant writings of both theologians and identifies concepts that are key to understanding the Syrian Christian vision of discipleship and the Christian life and provides some implications of that vision that yield valuable insights into models of discipleship and formation that can strengthen African Christians on the journey to Christlikeness.
\end{abstract}

Correspondence Joshua D. Settles Email: jdsettles@aci.edu.gh

Publication History Received 2nd February, 2022 Accepted 21st February, 2022 Published online 3rd March, 2022

Keywords: Aphrahat the Persian, Ephraim the Syrian, Christian Discipleship, African Christianity, the Church.

\section{INTRODUCTION}

The popular view of the history of Christianity is one often defined by the history of the West, and confined mostly to Europeans. It is a story wherein Jesus' commission to 'make disciples of all nations' led to the progression of the Christian faith in a steadily north and westward direction from Judea, into the GrecoRoman world, and from thence into northern and western Europe. The biblical narrative of Acts lends weight to this perception, focused as it is on events within the bounds of the Roman Empire. While there is usually some acknowledgment of Eastern Orthodoxy and nods given to the existence of other strands of Christian history, these stories elicit little sustained attention in Western scholarship and far less than that when it comes to mining the Christian past for perspectives on the discipleship of Christian believers. It is the Western European story that informs views of the ideal Christian life, shapes patterns of discipleship and out of which missiology is largely developed. The less well-known story of the early eastward missionary expansion of Christianity challenges the dominance of this narrative. Research indicates that it was from mission bases in what are now Syria, Iraq and Iran that the message of Christianity reached as far afield as Japan and as early as the $8^{\text {th }}$ century. ${ }^{1}$ Such was the dynamism of this Asian Christianity ${ }^{2}$ that it is entirely plausible to claim that 'the Nestorian church (as most of the early Asian Christian communities came to be

John Stewart, Nestorian Missionary Enterprise: The Story of a Church on Fire (Edinburgh: T\&T Clark, 1928), xxxi.

The interchangeable use of the terms 'Asian', 'Syrian', and 'Eastern' as descriptors of Christianity east of the Roman Empire is intended to signify both the origins and the extent of Christian witness in this era as well as to highlight the connection between this ancient story and the contemporary one. The distinctions between these, while important, are beyond the scope of this study. 
called) exercised ecclesiastical authority over more of the earth than either Rome or Constantinople. ${ }^{3}$ It was the most expansive missionary movement in history perhaps exceeding even that of the modern era.

All missionary movements in Christian history might be said to be undergirded by a particular vision of discipleship and the Christian life; this one is no exception. It is a vision that differs from that which emerged from the Greco-Roman philosophic tradition that came to so strongly influence Western Christianity. It reflects a different culture and a different primal religious context. This study aims to explore a bit of that vision as reflected in the teachings of two of the most prominent of the Eastern Church Fathers: Ephraim the Syrian and Aphrahat ${ }^{4}$ the Persian Sage.

\section{METHODOLOGY}

This study begins with a brief introduction to Ephraim and Aphrahat as representatives of early Eastern Christian thought. It then proceeds to an examination of the cultural and religious setting in which Syrian Christianity emerged, including descriptions of elements of Zoroastrian and Jewish religious thought that were antecedents to Christian faith in the area. Following that is a discussion of the origins of Syrian Christianity itself. Finally, the study identifies from the writings of Ephraim and Aphrahat concepts that are key to understanding the Syrian Christian vision of discipleship and the Christian life and provides some implications of that vision that yield valuable insights into models of discipleship and formation that can strengthen believers on the journey to Christlikeness.

Background to Ephraim and Aphrahat

Ephraim the Syrian and Aphrahat the Persian Sage both lived and wrote in the middle of the $4^{\text {th }}$ century. They are considered contemporaries to each other and to the Council of Nicea. Ephraim is the more lyrical of the two writers and composed a number of hymns 'making song an essential constituent of public worship, and an exponent of theological teaching.' Aphrahat was of Persian background and a convert to Christianity. John Gwynn describes him as 'the greatest Eastern theologian of the early fourth century and ... the most admirable of all the Christian thinkers of his time, East or West. ${ }^{6}$ Together these two writers are "fitly associated as examples of the leaders of Syriac thought and literature" ${ }^{9}$ and their writings are therefore the best source for information on how discipleship and the Christian life in early Syrian Christianity was perceived.

\section{Cultural and Religious Setting}

The Christianity that arose in the regions east of Palestine and largely outside the borders of the Roman Empire developed against a quite different cultural and religious background than what was obtained within that empire. While these territories had been part of Alexander the Great's Macedonian Empire and were undoubtedly influenced by the Hellenistic culture of that empire and her successor states, the older, primal traditions exerted their own, perhaps stronger, influences as well. Indeed the Bible is primarily situated in an Eastern context and dominated by Eastern cultural norms; these are realities easily overlooked if one examines only the New Testament corpus, and its implications for how one thinks of discipleship. Abraham, the 'wandering Aramean'8 patriarch of Israel had his origins there. It was into Babylon, in the east, that Israel was sent to captivity. A substantial amount of both the prophetic and historical literature of the Old Testament was written in and from the Eastern context including the books of Daniel, Esther, and Nehemiah. It was only after captivity in Babylon to the east of Israel that a more complex eschatology including the doctrine of the resurrection from the dead first came to be fully articulated during $2^{\text {nd }}$ Temple Judaism. ${ }^{9}$ Perhaps most

Samuel Moffett, A History of Christianity in Asia Vol.1: Beginnings to 1500 (Maryknoll, NY: Orbis Books, 1998), xiii.

Aphrahat is also known as Aphraates.

John Gwynn, 'Introductory Dissertation: Ephraim the Syrian and Aphrahat the Persian Sage', in Philip Schaff and Henry Wace (eds.), A Select Library of Nicene and Post-Nicene Fathers of the Christian Church, $2^{\text {nd }}$ Series, Volume XIII, Part II (Edinburgh: T\&T Clark, 1989), 119-162 (120).

6 Moffett, A History of Christianity, 125.

7 John Gwynn, 'Introductory Dissertation: Ephraim the Syrian and Aphrahat the Persian Sage' 119.

8 Deuteronomy 26.5-10.

9 Shaye J.D. Cohen, From Maccabees to the Mishnah (Philadelphia: Westminster Press, 1987), 22. 
intriguingly, it is from the East that the magi, mysterious sages,-come to offer homage to Jesus at his birth. ${ }^{10}$ It is clear then that Christianity owes much to these lands. Within these lands, Zoroastrianism, the religion of the Indo-Iranian people, exerted an undoubtedly strong influence.

\section{Zoroastrianism}

The Zoroastrian religion was already an ancient faith by the time of Christ. While 'no sound tradition exists about the date of Zoroaster'"11 the founder of the religion, Mary Boyce suggests that 'it seems natural to conclude that the prophet lived somewhere between, say 1400 and 1000 B.C.' 12 In any case, the religion would have been well established before the time of the Babylonian Captivity of the $8^{\text {th }}$ century B.C.

At the core of Zoroastrianism is the belief in a 'primeval unity in the sphere of the divine, ${ }^{13}$ a notion that has roots in pre-existing Indo-Iranian notions of "primeval simplicity and unity behind the diversity of physical phenomena' ${ }^{14}$ Zoroaster held that plurality and diversity were divergences from the ideal, realities that emerged 'only because of the existence also of evil divinity' ${ }^{15}$ Angra Mainyu who stands in opposition to Ahura Mazdā, the divinity within whom 'all divine goodness [is] comprehended'. ${ }^{16}$ Thus Zoroastrian religion embraces an essentially dualistic cosmology wherein equally powerful uncreated good and evil deities operate in active opposition to one another. This dualism seems to operate anteriorly to the emergence of the two deities, for they are asserted to have chosen between good and evil ${ }^{17}$ and thus the concept of choosing sides in a cosmic struggle that emerges as an idea deeply embedded in Persian religious consciousness. This cosmic struggle was not conceived as interminable, for although 'Angra Mainyu and his legions are formidable and inflict harm generally...in the end, the prophet was convinced, this dreadful power would be broken. ${ }^{18}$

\section{Judaism}

It is important to note the presence throughout these territories of substantial Jewish diaspora communities. Medes, Parthians, and Elamites are listed among those Jews of the diaspora present at Pentecost, people who 'represented the territory to the far east of Palestine, lying... outside the Roman Empire, but not beyond the Jewish dispersion'. ${ }^{19}$ There is evidence that these Jews may have been influenced by the Qumran community, a group who "believed themselves to be the "sons of the Covenant" and had separated themselves from ordinary Jewish life in order to seek a special holiness' ${ }^{20}$ Qumran was an ascetic sect that, according to Barrett, aimed to 'achieve a life of perfect purity' and therefore 'admission to the community was not easily granted and probation was severe.' ${ }^{21}$ Additionally, in a manner similar to that found in Zoroastrianism, Qumranic literature emphasises a cosmic struggle between light and darkness as is seen in the opening lines of a "War Scroll" of Qumranic literature: 'The first attack of the sons of light will be launched against the lot of the sons of darkness, against the army of Belial' ${ }^{22}$ It is not immediately evident if this section refers only to spiritual battle, or if it also includes the possibility of physical confrontation, but 'the supreme adversary of God and his people is the devil, and spiritual conflict there must be before the devil is overthrown and God

10 Matthew 2.1-2

11 Mary Boyce, A History of Zoroastrianism Volume 1: The Early Period (Leiden, The Netherlands: E.J. Brill, 1996), 3.

Boyce, A History of Zoroastrianism, 189.

Boyce, A History of Zoroastrianism, 192.

4 Boyce, A History of Zoroastrianism, 192.

Boyce, A History of Zoroastrianism, 192.

Boyce, A History of Zoroastrianism, 192.

7 Boyce discusses this in some detail on page 200-201.

Boyce, A History of Zoroastrianism, 233.

19 Charles K. Barrett, A Critical and Exegetical Commentary on The Acts of the Apostles Vol. 1 (Edinburgh: T\&T Clark, 1994), 123.

20 Leslie W. Barnard, 'The Origins and Emergence of the Church in Edessa during the First Two Centuries A.D.' Vigiliae Christianae Vol. 22, No. 3 (Sept. 1968), 161-175 (164), Accessed 14 February 2014, http://www.jstor.org/stable/1581930.

21 Charles K. Barrett, The New Testament Background: Selected Documents (London: SPCK, 1987), 228.

22 1QM Col 1., in Florentino Martinez and Eibert Tigchelaar, The Dead Sea Scrolls Study Edition Vol. 1: 1Q1 - 4Q273 (Leiden, The Netherlands: Wm. B. Eerdmans Publishing Co., 1997), 113. 
is seen as victorious. ${ }^{23}$ In either case, this provides a glimpse of the perspective of these Jewish communities on spirituality and cosmic conflict.

It is against the backdrop of these religious ideas that Syrian Christianity emerges in the earliest centuries of the church.

\section{Origins of Syrian Christianity}

The precise origins of Christianity in Edessa are in fact difficult to identify and to date, there are multiple theories as to its' beginnings. According to one ancient Assyrian tradition, the magi of Matthew 2 were in fact from Edessa and had initially travelled to Bethlehem in response to a $7^{\text {th }}$ century Zoroastrian prophecy. Writing about this tradition, T.V. Philip records that, 'on their return to Edessa they [the magi] had told of the wonderful things they had seen and heard and this prepared the minds of the Edessians for the reception of the gospel. ${ }^{24}$ Better known in the West is the story told by Eusebius. According to him, Christianity came to Edessa through the agency of Addai, one of the seventy disciples of Jesus who 'first preached to the Jews there and thus began the church in Edessa'. ${ }^{25}$ Indeed if one follows the New Testament pattern, it is certainly reasonable to suggest that it was among the Jewish diaspora within West Asian states like Edessa and Armenia that Christianity first spread. Though there are elements of the Addai tradition which appear to be legendary, 'there is reason to think that Addai was a historical figure and that... he was a Jew from Palestine'. ${ }^{26}$ Whatever the precise origin, it appears that the church in Edessa was founded early among Syriac speaking Jews and indeed, as J.B. Segal notes, 'Christian evangelists found in the Jewish communities tools ready to hand for the diffusion of their faith. ${ }^{27}$

The Syrian Church that did develop utilised a modified harmonized version of the four gospel accounts called the Diatesseron, composed by Tatian; a composition that, in Barnard's opinion, 'became the Gospel par-excellence of Syriac-speaking Christianity' ${ }^{28}$ Caught between the empires of Persia to the east and Rome to the west, smaller states like Osrhoene, with its capital at Edessa, found themselves subject to influence and domination by both. Edessa lay on the major trade routes between East and West, making it a natural locus of commerce as well as a point of nexus for new ideas from both East and West. One should note that during this era 'Edessa lay in the Parthian, not the Roman sphere of interest, and its people spoke Syriac, not Greek; ${ }^{29}$ a fact that highlights an eastward orientation and thus the connection with Persia and Persian religious thought. It is against this backdrop of religion and culture that the examination of the writings of Ephraim and Aphrahat proceeds.

\section{The Nature of the Christian Life}

While the writings of Ephraim and Aphrahat cover a broad range of subject matter, several themes rise to the surface that provide some insight into what these two writers perceived as key to discipleship and the Christian life. One of the most prominent of these is the notion of the triumph by Jesus over Death as the point of departure for the Christian life itself.

\section{The Defeat of Death}

Dealing with death and the fear of death is an important theological question to which almost all religious systems address themselves. It is no less an important issue in the lives of Africans, whether Christian or not, evidenced by the importance placed on appropriate death rituals in most African cultures. That it was an especially significant problem for the Syrian recipients of the gospel is more understandable when it is kept in mind the backdrop of Zoroastrian religion with its view of the cosmic struggle between good and evil, between life and the nullification of life that death represents. That Edessa was a buffer state between

\footnotetext{
23 Barrett, The New Testament Background, 246.

24 T.V. Philip, East of the Euphrates: Early Christianity in Asia (India: CSS \& ISPCK, 1998), Chap. 2, para. 7, https://www.religion-online.org/book-chapter/chapter-2-christianity-in-edessa/.

25 Philip, East of the Euphrates, Chap. 2, para. 8.

26 Barnard, 'The Origins and Emergence of the Church in Edessa', 162.

27 Judah B. Segal, Edessa: The Blessed City (Piscataway, N.J.: Gorgias Press, 2001), 42.

28 Barnard, 'The Origins and Emergence of the Church in Edessa', 169.

29 Segal, Edessa, 65.
} 
the power of Persia and Rome and thus subject to all the horrors and disruptions of periodic warfare likely amplified this fear. Conversion to Christ did not automatically eliminate this concern and it was, therefore, one to which Christian discipleship necessarily addressed itself.

In his hymns, Ephraim writes about the defeat and disempowerment of Death, conceived of as the great enemy of humanity. Ephraim declares of Jesus, 'Our King living has gone forth and gone up, out of Hell, as Conqueror... to evil spirits and demons He is sorrow, to Satan and to Death He is pain, to Sin and Hell mourning'. ${ }^{30}$ As the hymn continues, Death complains, 'Lo! This suffering which I cause men to suffer in their beloved ones, in the end on me it gathers itself together.' ${ }^{31}$ Three important elements of Christian discipleship emerge from this vision that Ephraim so cleverly emphasises. The first element is a reflection on the scriptures, particularly on the story of Jesus.

If a man read in the Prophets, he hears thereof righteous wars. But if a man mediates in the story of Jesus, he learns of grace and tender mercy. And if a man thinks of Jesus, that He is a strange God it is a reproach against me. No other strange key into the gate of Sheol could ever be fitted. One is the key of the Creator, that which has opened it, yea, is to open it at His Coming. ${ }^{32}$

Meditation on scripture becomes for the Christian an instrument of reproach against Death and thus an important tool in the hand of the believer. Reflection on Jesus, the 'strange key' that opens the gates of hell and leads to freedom for those held therein is seen as vital. Secondly, Ephraim emphasises the importance of acknowledging one God over against many gods, and in fact declares the impotency of those gods in the crucial matter of defeating Death.

Mortals that have erred and preached that there are Gods many, lo! They are bound for me in Sheol, and their Gods have never grieved because of them. ${ }^{33}$

The 'Gods many' proclaimed by others are powerless because they lack the capacity to rescue humanity from Death's power. Those who preach many gods are themselves bound for the grave and their gods will not grieve them. ${ }^{34}$ Finally, Ephraim stresses the primacy of the scripture. Death declares, 'One God do I know, and His Prophets and His Apostles do I acknowledge.' ${ }^{35}$ The terms 'His Prophets and His Apostles' may be taken as references to the Old and New Testament scriptures. The centrality of Jesus, the acknowledgment of one God, and the authority of scripture are key weapons in the arsenal of faith.

The focus on the conquest of Death comes through again in a more direct fashion in Ephraim's homily 'On Our Lord'. The opening section of the homily does not centre on the cross, nor on salvation from sin as the departure point of Christian experience, but on Christ's resurrection 'as a pledge to mortals, that $\mathrm{He}$ would remove them from Sheol'. ${ }^{36}$ The salvific emphasis here is clearly on rescue from the power of Death. Jesus is described pre-eminently as the one who 'was trampled on by Death; and in His turn trod out a way over Death', who 'entered Sheol and plundered its storehouses and emptied its treasures' ${ }^{37}$ Christ's ultimate triumph over death is a key to the vision of early Asian Christianity and consequently undergirds the vision of Christian discipleship.

Aphrahat takes up the theme as well, personifying Death as one who 'hoped that he would bind fast all the sons of man and would be king over them forever' 38 but because 'Jesus, the slayer of Death came,

30 Ephraim, 'Nisibene Hymns XXXVI' in Philip Schaff and Henry Wace (eds.), A Select Library of Nicene and Post-Nicene I Fathers of the Christian Church, $2^{\text {nd }}$ Series, Volume XIII, Part II (Edinburgh: T\&T Clark, Reprinted 1989), 167- 219 (198).

31 Ephraim, 'Nisibene Hymns XXXVII', 198.

32 Ephraim, 'Nisibene Hymns XXXVII', 199.

33 Ephraim, 'Nisibene Hymns XXXVII', 199.

34 There is another point here as well, to which we shall return later, which is that the preaching of false gods is described not as an act of intention but of error; their proclaimers, though not innocent, are victims of an error into which they fall.

35 Ephraim 'Nisibene Hymns XXXVII', 199.

36 Ephraim, 'Three Homilies' in Philip Schaff and Henry Wace (eds.), A Select Library of Nicene and Post-Nicene Fathers of the Christian Church, $2^{\text {nd }}$ Series, Volume XIII, Part II (Edinburgh: T\&T Clark, 1989), 305-341 (305).

37 Ephraim, 'Three Homilies: On our Lord', 306.

38 Aphrahat, 'Demonstrations XXII', in Philip Schaff and Henry Wace (eds.), A Select Library of Nicene and Post-Nicene Fathers of the Christian Church, $2^{\text {nd }}$ Series, Volume XIII, Part II (Edinburgh: T\&T Clark, Reprinted 1989), 345-412 (402). 
and clothed Himself in a Body from the seed of Adam...Death tasted the medicine that was deadly to him, and his hands dropped down, and he learned that the dead shall live and escape from his sway. ${ }^{39}$ In this way, Aphrahat highlights the importance of the resurrection in Syrian Christian thought; Death does not have final authority or victory over the Christian. The Christians are therefore to live, 'as sojourners [who] dwell in the world, and prepare for themselves a provision for the journey before them'. ${ }^{40}$ The implication is that since Death has been defeated, it is no longer to be feared by the Christian, but is better understood as a means through which 'prisoners are released, and fear not again' ${ }^{41}$ Consequently and as a practical matter, Christian's lives are to be marked by a certain sobriety as they 'afflict themselves in the place of their sojourning', ${ }^{42}$ a quality that was deeply rooted in Christian thought of early Eastern Christianity.

\section{The Ascetic Life}

While the conquest of death through the work of Christ led to a certain austerity of thought about the nature of the Christian life, it must be understood that this was not related only to questions of death and resurrection. Indeed, Syrian Christianity was 'permeated at its core by an ascetic outlook'. ${ }^{43}$ That is to say, the Christian life was viewed in primarily ascetic terms and that to become a Christian was to become a member of a particular kind of exclusive holy community. Certainly, it is noteworthy that one of Aphrahat's Demonstrations is addressed 'Of Monks' ${ }^{44}$, a term alternately translated 'Sons of the Covenant' ${ }^{45}$ It is interesting in part because of the Qumramic precedent in the use of the term. As noted earlier, the Qumram community used the term in reference to itself as a covenantal community "associated with a "vow" [that] required a total commitment which had to be renewed each year' ${ }^{46}$ It seems plausible therefore to infer at least an ideological link between the Qumran expression of Jewish sectarianism and the Christianity that developed in the East. In fact, given the proximity of the communities and the large Jewish presence in Edessa, it is quite possible that the link was more than ideological but that Jews who had been part of Qumran or were influenced by its religious ideas were also part of the early church there in Edessa. If this is the case then it helps explain why Syrian Christians, like their Jewish Qumran counterparts 'were not concerned with social duties or with marriage as such, but had come apart to seek total purity of life.' ${ }^{47}$

This ascetic principle was especially true as it related to views on marriage. Aphrahat deems celibacy to be the superior or at least preferential state for the Christian believer and therefore those who wish to marry are advised to do so before they are baptized. He admonishes preachers to warn those in the 'covenant of God' that choosing baptism is to 'choose for themselves virginity and holiness' and choosing to 'empty himself for the strife, for [the believer] may not be mindful of anything which is behind and turn back to it' ${ }^{48}$ He further counsels that 'whatever man desires to continue in holiness, let not his spouse dwell with him, lest he turn back to his former condition, and so be esteemed an adulterer. ${ }^{49}$ So strict is the lifestyle enjoined that abandonment of this type of self-restraint, even to return to cohabiting with one's spouse, could be construed as committing adultery. Christian discipleship thus involves a kind of total renunciation of the world, including marriage, in a way that is frequently associated with monasticism. Yet here it is not only monastics who were expected to adhere to this kind of discipline, but the church at large. Leslie W. Barnard contends that 'B'Nai Q'yama (Children of the Covenant)' later developed as a 'kind of monastic order within the Christian community' ${ }^{50}$ but in Aphrahat's time the whole of the 'baptized laity of the church' ${ }^{51}$

39 Aphrahat, 'Demonstrations XXII', 403.

40 Aphrahat, 'Demonstrations XXII', 405.

41 Aphrahat, 'Demonstrations XXII', 405.

42 Aphrahat, Demonstrations XXII, 405.

43 Barnard, 'The Origins and Emergence of the Church in Edessa', 175.

44 Aphrahat, 'Demonstrations VI, 362.

45 Moffett makes this observation in Moffett, A History of Christianity in Asia, 125.

46 Barnard, 'The Origins and Emergence of the Church in Edessa', 164.

47 Barnard, 'The Origins and Emergence of the Church in Edessa', 164.

48 Aphrahat, 'Demonstration VII, 20: On Penitents' in Journal of the Society of Oriental Research, 16 (1932); 43-56, translated by Frank H. Hallock. http://www.tertullian.org/fathers/aphrahat_dem7.htm.

49 Aphrahat, 'Demonstration VI, 4'.

50 Barnard, 'The Origins and Emergence of the Church in Edessa', 164.

51 Barnard, 'The Origins and Emergence of the Church in Edessa', 164. 
viewed themselves in this way. Whether or not this is the case, it is clear that a monastic ascetic lifestyle was celebrated by the early Syrian Christian community.

This ascetic impulse is evident in Ephraim's writings as well. The virginal celibate life is praised by Ephraim and he describes virginity as a prey stalked on every hand by her enemies:

And lo, in the chamber and lo, in the field they are lying in wait for thee, O Virginity! Thou didst enter the chamber; the cunning Amnon stole thy wealth; thou didst go forth into the field, the brigand Shechem robbed thy treasure. Whither wilt thou go, O lonely Dove? For lo, many in every place are they that hunt for thee! ${ }^{52}$

Virginity is therefore something to be cherished and zealously guarded, protected from those who would steal from her. Virginity is the preferred state for living the Christian life and indeed Ephraim's entire discourse on the matter opens with an admonition to, 'put off, O Body, that Old Man which is altogether hateful, that it may not wear out the newness that thou inhabitest and hast put on. ${ }^{53}$ Any distinction between marital and non-marital sexual activity seems irrelevant here; it is celibacy that is celebrated. Later Ephraim speaks of 'the humble ones [who] have stolen away from marriage under the pretext of discipleship'. ${ }^{54}$ Christian discipleship is described as a path that takes one away from marriage. Those who are unable to endure this path and are ashamed to return to the marital state 'fall and are taken in the snares [of the sinful nature]' ${ }^{55}$ Thus marriage is at best a kind of fallback position for those Christians unsuited for the rigors of discipleship, and possibly a rather shameful one at that.

\section{Spiritual Battle}

The last element of discipleship and the Christian life is that of the Christian life understood as active engagement in battle. As stated previously, Syrian Christianity emerged against the backdrop of the geopolitical conflict between the empires of Rome and Persia, and in the context of a religious and cultural system that understood life as a cosmic war between good and evil into which humans are inevitably drawn. As in any conflict, this spiritual one has victims who are wounded, combatants who are captured, and enemies who seek to undermine success. In Zoroastrianism, 'a person in the grip of rage or hatred was regarded as the victim of an external foe, no less than one who shook with fever or was palsied,' and therefore any sinful actions he took 'were regarded as an evil into which the particular demon had trapped him'. ${ }^{56}$ This notion is carried forward into Christian thought as well. Aphrahat writes of the 'sons of Adam' who have been 'smitten and beaten' ${ }^{57}$ by sin, the external foe of humanity. Aphrahat continues:

The man whom Satan has smitten ought not be ashamed to confess his sin, and depart from it, and entreat for himself the medicine of penitence...so for him who has been conquered in our conflict, there is this way that he may be healed, when he shall say, "I have sinned", and shall entreat penance. ${ }^{58}$

Thus the spiritual battle is at the forefront of his understanding of the Christian life and frames his approach to dealing with sin. To be clear, the Christian who sins is not seen merely as a victim of forces beyond his control as in the Zoroastrian example, for there is an exhortation for the sinner to confess his sin, thus implicitly accepting responsibility, but an acknowledgment of the spiritual battle looms larger in understanding the whole Syrian approach to the Christian life. 'Learn the arts of war' Aphrahat cries, 'lest ye be conquered and thrown down in battle. Our enemy is cunning and skillful, but his arms are weaker than ours. ${ }^{159}$

52 Ephraim, 'Discourse on Virginity: XXII' in S. Ephraim's Prose Refutations of Mani, Marcion and Bardaisan, Vol. 2 (1921), transcribed from Palimpsest B.M. Add. 14623 by C. W. Mitchell. Accessed 22 February 2014, http://www.tertullian.org/fathers/ephraim2 6 virginity.htm\#lxxxi.

53 Ephraim, 'Discourse on Virginity: I'.

54 Ephraim, 'Discourse on Virginity: VI'.

55 Ephraim, 'Discourse on Virginity: VI'.

56 Boyce, A History of Zoroastrianism, 87-88.

57 Aphrahat, 'Demonstration VII, 1'.

58 Aphrahat, 'Demonstrations VII, 3'.

59 Aphrahat, 'Demonstrations VII, 7'. 
Aphrahat again speaks of the diligence with which a believer ought to live in view of the constant battle being waged against him by Satan.

In the hour in which he [the believer] perceives in himself that he is not fervent in the Spirit, and that his heart is inclining to the thought of this world, he may know that the Spirit is not with him, and may arise and pray and keep vigil that the Spirit of God may come to him that he be not overcome by the adversary...Satan cannot draw near to that house which is our body, until the Spirit of Christ departs from it. ${ }^{60}$

Furthermore, in Aphrahat's view, the Holy Spirit does not dwell continuously in a believer's body. As he puts it, 'the Spirit is not at every time found with those that receive it', ${ }^{61}$ but from time to time returns to God to report on how he is being kept. Hence, the believer is particularly vulnerable to assault by the enemy, and thus the admonition for extra vigilance during those times. If however the Christian is engaged in 'speaking shameful words, or [is] enraged, or quarrelling, or contending, then Satan knows that Christ is not with him and he comes and accomplishes his will in him. ${ }^{62}$ Thus Christians must always be on their guard. Ephraim picks up on this idea as well in his extended poetic description of the sinful woman who washed Jesus' feet with her hair. ${ }^{63}$ Throughout his discourse on the woman, Satan appears as a crafty enemy who seeks to entrap the woman and prevent her from carrying out her repentance. Because of his craftiness, Ephraim reminds the believer 'our Lord has taught us not to raise our voice when we pray, that the Devil may not hear our words and draw near and become our adversary. ${ }^{\prime 64}$ The instruction calls to mind antiespionage posters displayed during wartime to encourage citizens to refrain from careless talk lest enemy spies overhear. Believers are at war and even the saying of prayers must be done in awareness of this fact.

\section{The Legacy of the Church}

It is a tragedy that so much of the legacy of this church has been lost because 'less than two hundred years after the death of Christ, Syrian Christians were beginning to carry the faith...out across the continent toward the steppes of the central Asiatic nomads and the edges of the Hindu Kush. ${ }^{65}$ However, the vision of discipleship and the Christian life held by these early believers and captured in the writings of Ephraim the Syrian and Aphrahat the Persian Sage provides valuable insights that are of particular relevance to Christian believers in Africa for whom issues of death, asceticism, and spiritual battles have special resonance. One may only speculate of course as to how much these beliefs were connected directly to the missionary impact of 'the Church of the East, as the church that carried the gospel to these eastern lands is officially designated' ${ }^{66}$ Even so, it is impossible that these beliefs had no impact at all and there is much one can learn from them. Firstly, Syrian Christians understood in a profound way the central importance of Christ's resurrection and its implications for the destruction of the power of death over the life of a believer. Because they understood the significance of Christ's defeat of death, they were perhaps empowered to live more fully abandoned to the mission of God and more fully committed to spreading the gospel at whatever cost to themselves or their physical well-being. This attitude of self-abandonment may have been an important component of their ability to cope with the constant uncertainties of war and political instability but more importantly, has proven over time to be a prerequisite for a successful Christian mission. This stands in marked contrast to the temporal material prosperity and security that finds frequent expression in many African Christian settings. This is a reaffirmation of what salvation had meant within the traditional African religion, which has to do with deliverance from those 'physical and immediate dangers that threaten individual or community survival, good health, and general prosperity or safety. ${ }^{97}$ The emphasis on abandoning oneself to the cause

\footnotetext{
60 Aphrahat, 'Demonstrations VI, 17'.

61 Aphrahat, 'Demonstrations VI, 16'.

62 Aphrahat, 'Demonstrations VI, 17'.

63 Ephraim, 'Three Homilies: On the Sinful Woman', 336-341.

64 Ephraim, 'Three Homilies: On the Sinful Woman', 338. This admonition to quietness in prayer presents an interesting contrast to prayer practices in many contemporary Ghanaian contexts where loudly vocalized prayer is emphasized.

65 Moffett, A History of Christianity in Asia, 80.

66 Stewart, Nestorian Missionary Enterprise, xxx.

67 John S. Mbiti, 'God, Sin, and Salvation in African Religion', The Journal of the Interdenominational Theological Center, Vol.16, No. 1-2 (Fall1988) ; 59-68 (69).
} 
of mission and of Christ recalls the idea of total devotion to a shrine or deity in the primal religions of Africa that seem to be increasingly lost in contemporary Christian practice with its focus on socioeconomic advancement and "the good life". This brings to the fore a second key feature, which is that they saw the adoption of an ascetic lifestyle as something all Christians were called to embrace, an attitude that, no matter how incompletely lived out, was sure to minimize nominal and insincere embrace of Christian faith. It is hard to imagine that any would view Christian commitment as anything other than radical given the vision of that commitment expressed by Ephraim and Aphrahat. This approach to discipleship again confronts 'belief in a gospel of success, upward mobility and achievement, ${ }^{68}$ which is so prominent among African Christians and hinders the call to deep communion with the Lord. Finally, they lived with a keen awareness of the spiritual realm and of the constant battle being waged. This too resonates with the African primal spirituality that finds continued expression in the life of the African church. Though they were confident of Jesus' final and complete triumph, the cost of engaging in that fight and the need for vigilance was never far from their minds. To enlist as a Christian was to enlist as a soldier with all the risk that entailed. Such was the life envisioned by Ephraim and Aphrahat for Christians.

\section{CONCLUSION}

There is much more to be learned from these early exponents of our faith, and much more to be gleaned from their vision of the Christian life than can be explored here. Their message continues to speak across time, reminding Christians of the need to be humble, vigilant and faithful to Christ and to take seriously the call to discipleship. It is perhaps fitting then to with these words from Aphrahat:

I have written for our brethren and beloved, the children of the Church of God, that when these come into their hands in various places, and when they read in them, they may also remember my insignificance in their prayers, and may know that I am a sinner also, and fall short. ${ }^{69}$

\section{BIBLIOGRAPHY}

Aphrahat, 'Demonstration VII: On Penitents', in Journal of the Society of Oriental Research Vol. 16, (1932), 43-56, translated by Frank H. Hallock. Accessed 22 February 2014 http://www.tertullian.org/fathers/aphrahat_dem7.htm

Aphrahat, 'Demonstrations', in Philip Schaff \& Henry Wace (eds.), A Select Library of Nicene and PostNicene Fathers of the Christian Church $2^{\text {nd }}$ Series, Vol. XIII (Edinburgh: T\&T Clark, Reprinted 1989), 345-412.

Asamoah-Gyadu, Johnson Kwabena, Sighs and Signs of the Spirit: Ghanaian Perspectives on Pentecostalism and Renewal in Africa (Akropong-Akuapem: Regnum Africa, 2015).

Barnard, L.W., 'The Origins and Emergence of the Church in Edessa during the First Two Centuries A.D.', in Vigiliae Christianae Vol.22, No. 3 (1968),pp. 161-175. Accessed 14 February 2014. http://www.jstor.org/stable/1581930

Barrett, C.K., A Critical and Exegetical Commentary on The Acts of the Apostles Vol. 1. (Edinburgh: T\&T Clark, 1994). . The New Testament Background: Selected Documents (London: SPCK, 1987).

Boyce, Mary, A History of Zoroastrianism Volume 1: The Early Period (Leiden, The Netherlands: E.J. Brill, 1996).

Cohen, Shaye J.D., From Maccabees to Mishnah (Philadelphia: Westminster Press, 1987).

Ephraim, 'Discourse on Virginity', in S. Ephraim's Prose Refutations of Mani, Marcion and Bardaisan, Vol. 2. (1921) transcribed from Palimpset B.M. Add. 14623 by C.W. Mitchell. Accessed 22 February 2014, http://www.tertullian.org/fathers/ephraim2_6_virginity.htm\#lxxxi

Ephraim, 'Nisibene Hymns', in Philip Schaff and Henry Wace (eds.), A Select Library of Nicene and PostNicene Fathers of the Christian Faith $2^{\text {nd }}$ Series, Vol. XIII (Edinburgh: T\&T Clark, Reprinted

68 Johnson Kwabena Asamoah-Gyadu, Sighs and Signs of the Spirit: Ghanaian Perspectives on Pentecostalism and Renewal in Africa (Akropong-Akuapem: Regnum Africa, 2015), 48.

69 Aphrahat, 'Demonstrations XXII, 25'. 
1989), 167-219.

Ephraim, 'Three Homilies', in Philip Schaff and Henry Wace (eds.), A Select Library of Nicene and PostNicene Fathers of the Christian Faith $2^{\text {nd }}$ Series, Vol. XIII (Edinburgh: T\&T Clark, Reprinted 1989), 305-341.

Gwynn, John, 'Introductory Dissertation: Ephraim the Syrian and Aphrahat the Persian Sage' in Philip Schaff and Henry Wace (eds.), A Select Library of Nicene and Post-Nicene Fathers of the Christian Faith $2^{\text {nd }}$ Series, Vol. XIII (Edinburgh: T\&T Clark, Reprinted 1989), 119-162.

Moffett, Samuel, A History of Christianity in Asia Vol. 1: Beginnings to 1500 (Maryknoll, NY: Orbis Books, 1998).

Mbiti, John S., 'God, Sin, and Salvation in African Religion', The Journal of the Interdenominational Theological Center, Vol. 16, No. 1-2 (Fall1988), 59-68.

Philips, T.V., East of the Euphrates: Early Christianity in Asia (India: CSS \& ISPCK, 1998), Accessed 24 February 2014, http://religion-online.org/showchapter.asp?title=1553\&C=1361.

Segal, J.B., Edessa: The Blessed City (Piscataway, NJ: Gorgias Press, 2001).

Stewart, John, Nestorian Missionary Enterprise: The Story of a Church on Fire (Edinburgh: T\&T Clark, 1928).

Tigchelaar, Florentino Martinez \& Eibert, The Dead Sea Scrolls Study Edition Vol. 1: 1Q1- 4Q273 (Leiden: Wm B. Eerdmans Publishing Co., 1997).

\section{ABOUT AUTHOR}

Joshua D. Settles is a Research Fellow, at the Centre for Primal \& Christian Spirituality - Akrofi-Christaller Institute of Theology, Mission, and Culture, Akropong - Akuapem, Ghana. 